\title{
Drug pricing reforms promising but problematic
}

Cite as: CMAJ 2017 July 4;189:E899-900. doi: 10.1503/cmaj.1095436

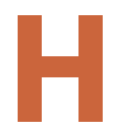

ealth Minister Dr. Jane Philpott recently launched an online consultation of a suite of reforms aimed at giving Canada's Patented Medicine Prices Review Board (PMPRB) the regulatory teeth to protect Canadians against excessive prices. The proposed reforms include overhauling how the board determines whether a drug price is too high, changing the countries used for price comparisons, and requiring drug companies to disclose the discounts they negotiate with different payers in Canada. The online consultation is scheduled to run until June 28 .

"Collectively, these changes might reflect a significant improvement in consumer protection," says Steven Morgan, a professor in the School of Population and Public Health at the University of British Columbia. However, "there is a lot of room for the drug manufacturers and industry to push back and make this into an exercise where we'll end up with a continued lack of strong regulatory enforcement."

Canadians pays some of the highest drug prices in the world, second only to the United States and Mexico, and the PMPRB has been part of the problem, Morgan says. One major flaw is that the board benchmarks against countries with high drug prices. Back when the PMPRB was created 30 years ago, it was thought this would attract higher levels of pharmaceutical investment, but "Canada didn't get the bargain it thought it would," he explains. The percentage of sales drug companies reinvest in Canadian research and development has dropped to a record low of $4.4 \%$, well below the minimum $10 \%$ promised by industry and average $20 \%$ invested in comparable nations.

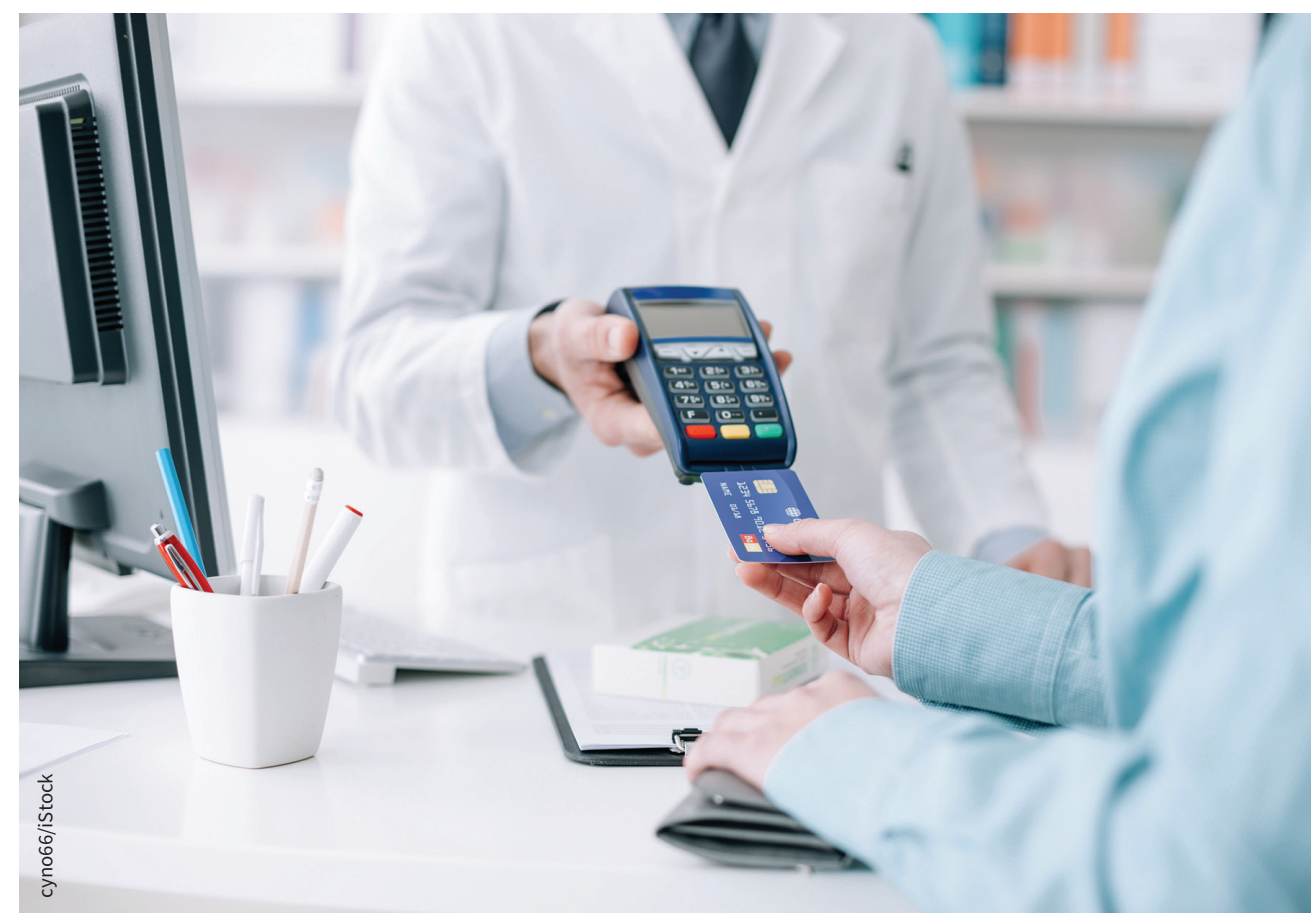

Canada is overhauling its drug pricing system, but Canadians won't see major savings without a singlepayer model, say experts.

\section{Comparator countries}

The federal government is proposing to update the countries used for price comparisons, dropping high paying outliers like the United States and Switzerland, and adding seven peers with more reasonable prices: Australia, Belgium, Japan, Netherlands, Norway, South Korea and Spain.

"Those are very good comparators," says Amir Attaran, a law professor at the University of Ottawa who studies drug pricing. "They have similar wealth to Canada, with some smaller and others larger." However, drug companies may balk at the inclusion of so many European Union countries, "since there are common regulatory requirements in the EU which cut their compliance costs."
Even without adding new countries, Morgan says that cutting the United States from the comparator list will "bring down the reference for Canadian prices a lot because the Americans are just so off the charts."

\section{Disclosing discounts}

Another major problem is that the PMPRB bases its cost comparisons on public list prices, even though it's well known that drug companies secretly negotiate substantial discounts and rebates, cutting the true cost of medicines by as much as $50 \%$ for some countries.

In Canada, where federal, provincial and private drug plans each negotiate prices with companies, this may also create 
regional disparities. "These are secret deals so we don't know, but I would guess that there are major differences between wealthier or larger provinces," says Dr. Joel Lexchin, professor emeritus in health policy at York University in Toronto.

To level the playing field, the federal government is proposing to require drug companies to disclose any discounts it gives Canadian payers. However, Lexchin argues the impact of this reform is undercut by the fact that Canadian deals are still pegged to inflated international list prices. He says it would be more useful to know what other countries actually pay, and negotiate from there.

\section{Value-for-money}

Morgan argues it may be better still to shift the focus of pricing reviews to what Canadians are actually able to pay. The government seems to be attempting to do just that. It's proposing that the PMPRB consider the value for money and potential market for a drug, as well as Canada's gross domestic product, when determining if a price is too high. Another proposal to cap prices at a fixed cost per quality-adjusted life year might bring down the cost of extraordinarily expensive drugs, particularly those for rare conditions, says Morgan. "It's intensely difficult to understand the clinical implications of some of these treatments because of the quality of the scientific data; it's difficult ethically because of the vulnerability of the patient groups involved; and it's difficult economically because the prices defy conventional logic both on value for money and reasonable return on research and development."

However, Lexchin cautions that a dollar-for-value cap will only reduce prices in a meaningful way if it's a hard limit. The United Kingdom's experience with such thresholds shows that bending the rules to "special pleading" ultimately undermines the system. "With cancer drugs, the UK decided they would evaluate and pay for those out of a special fund but that fund has now blown its budget, so it all depends on how strictly the limit is going to be applied," explains Lexchin.

It's also difficult to get a sense of the value of a drug without a good picture of what the manufacturer spent on research and development, he adds. "The industry always claims prices have to be high because of how expensive it is to bring a new drug to market, but that may or may not be true since no one gets to see the figures."

\section{Reforms insufficient}

The bottom line is that Canada doesn't have the negotiating power to demand disclosure of research and development costs, or for drug companies to reveal the discounts they give to other nations. "What you really need to get prices low is monopoly buying power," says Lexchin. "You need a single buyer who can drive a price for the entire country and that's not the PMPRB."

Attaran agrees. If Canada tied marketing approval to acceptance of a price, and made health deals with the provinces contingent on accepting a national drug formulary, "then it would be impossible for provinces to cut corners on the medicines they offer," he says. The federal government isn't making moves on either of these issues, "so Canada will remain an inferior place for access."

Morgan says the tight timeline to complete the reforms by 2018 shows that Philpott "clearly wants to get something done," and the federal Liberals may be setting themselves up to campaign on a pharmacare promise in the next election. "The problem with kicking that can down the road is that windows of political opportunity are rare," he says. The current alignment of progressive governments in Ontario, Quebec and Alberta might change as provinces head to the polls in the next 12 to 16 months.

It's also concerning that the pharmaceutical industry isn't pushing back on the proposed reforms, at least not publicly, he says. "When industry is literally at the ribbon cutting ceremony, it usually means the prices are going up not down."

Innovative Medicines Canada, the association representing brand name drug companies, is still in the process of evaluating the proposed changes, says President Pamela Fralick. "However, the innovative pharmaceutical industry looks forward to working with the federal Minister of Health, Jane Philpott, on how we can together provide affordable and earlier access to innovative medicines for all Canadians."

\section{Lauren Vogel, CMAJ}

